\title{
FEATURE \\ Eco-intensification through soil carbon sequestration: Harnessing ecosystem services and advancing sustainable development goals
}

Rattan Lal

$\mathrm{L}$ and misuse and soil mismanagement, causing land trauma and severe degradation (Steinbeck 1939; Jacks and Whyte 1939; Wood 1951; Buck 2012), must be replaced by a judicious land use and prudent soil/crop/water management to restore degraded soils and improve the environment. The rapid increase in agricultural production since the 1960s has been caused by massive input of fertilizers (nitrogen $[\mathrm{N}]$, phosphorus $[\mathrm{P}]$, and potassium [K]), pesticides, energy use in plowing and other farm operations, and irrigation of about 350 Mha $\left(8.645 \times 10^{8}\right.$ ac) of land (Smil 2003; Tilman et al. 2001; Arizpe et al. 2011; Gomiero 2016). However, such an indiscriminate intensification through plowing, flood-based irrigation, and high inputs of chemicals has strong adverse effects on the quality and functionality of soil, water, air, vegetation, and biodiversity (Benson 2014). Despite these massive inputs, agronomic production of food staples has stagnated in some regions (Grassini et al. 2013), and new approaches to food production must be identified in the face of climate change (Beddington et al. 2012; Foley et al. 2011; Lal 2016a, 2018). Thus, the use of nutrients and pesticides, as well as rates and mode of application, in agroecosystems must be revisited (Drinkwater and Snapp 2007).

Advancing food security has numerous dimensions: reducing waste, improving distribution, increasing access, enhancing retention by improving human health, and increasing agronomic production. For meeting the food demand of 9.8 billion by 2050 with growing preferences for animalbased diets, it is argued that the agronomic production may have to be increased by $70 \%$ to $110 \%$ of the level in 2005 (FAO 2002; Alexandratos and Bruinsma 2012; Bruinsma 2009; Gomiero 2016), along with increase in the cropland area by as much as 150 Mha $\left(3.71 \times 10^{8}\right.$ ac) $(\mathrm{FAO}$

Rattan Lal is a distinguished university professor of soil science and the director of the Carbon Management and Sequestration Center at The Ohio State University, Columbus, Ohio. and ITPS 2015; Lambin et al. 2013). The additional demand for land resources is exacerbated by soil degradation (Oldeman 1994) and conversion to nonagricultural uses including urbanization (Lal 2017). As much as $25 \%$ of the agricultural land resources are strongly degraded (Oldeman 1994; Bai et al. 2008; Bindraban et al. 2012; FAO and ITPS 2015; Rekacewicz 2008), and the risks of additional degradation may be exacerbated by the projected climate change because of possible increase in precipitation intensities (Michael et al 2005). Identifying systems of maintaining or improving agronomic productivity, without degrading soil fertility or polluting the environment, is an important goal especially in emerging economies (e.g., India and China). Further, soils of agroecosystems must be managed in a manner that minimizes adverse impacts on the environment. An effective erosion control, based on sound measurement techniques (Brandt et al. 2018), and prevention of soil structural degradation (Grandy et al. 2002) are important considerations. Thus, there is a need for a paradigm shift in managing soils of agroecosystems.

Eco-intensification (EI), designed to restore soil organic carbon (SOC) and soil inorganic C (SIC) stocks of degraded soils, is an option to bring about the desired paradigm shift. Sustainable management of SOC, to maintain stocks above the threshold level of $1.5 \%$ to $2.0 \%$ in the root zone, is essential to sustaining productivity while restoring the environment. The SOC stock may be enhanced by land use and management systems that create a positive $\mathrm{C}$ budget in the root zone. The strategy of EI may be implemented through adoption of conservation agriculture (CA). Conversion of conventional plowing to CA (based on no-till $[\mathrm{NT}]$, mulch farming and cover cropping, complex rotation, and integrated nutrient management) may enhance SOC concentration and also reverse the soil degradation trends. While CA is neither a panacea nor a one-size-fits-all, the goal is to make it work for site-specific conditions because of numerous cobenefits. Thus, the objective of this article is to describe principles and techniques of EI through soil C management and sequestration, and explain technological options including importance of CA systems. This review is based on the hypothesis that the dilemma of degrading agricultural soils and increasing food demand can be effectively addressed through restoration of soil health by SOC sequestration and the attendant improvement in soil quality through the strategy of EI.

\section{ECO-INTENSIFICATION AND CONSERVATION AGRICULTURE}

EI is defined as intensification of biological processes supporting ecosystem services on medium-term (efficiency of management options) and long-term (sustainability of management option) basis (Gaba et al. 2014). A system-oriented CA (Lal 2015) encompasses a site-specific combination of (1) NT, (2) residue mulching, (3) complex rotations including cover cropping during the off-season, and (4) integrated nutrient management based on a judicious use of organic and inorganic sources of plant nutrients. The strategy is to fine-tune a site-specific system that creates a positive soil/ecosystem C budget on a long-term basis. Thus, the input of biomass- $\mathrm{C}$ into the soil (by residue retention, cover cropping, and amendments) must exceed the losses (by decomposition, erosion, and leaching). While decomposition of biomass is essential to maintaining the desired activity and species diversity of soil biota, losses of SOC by accelerated erosion (though water, wind, tillage, gravity, etc.) must be curtailed. Basic concepts of CA are also in accord with those of EI for "producing more from less" by enhancing the use efficiency and reducing losses (Lal 2010). The goal is to produce more per unit area of land, fertilizers and pesticides, irrigation, energy, and emission of greenhouse gases. With this strategy, the land area needed for cereal production can be decreased rather than increased (Lal 2016a).

Whereas the usefulness of CA has been recognized since the 1940s (Faulkner 1943), its adoption on about 180 Mha 
$\left(4.45 \times 10^{8} \mathrm{ac}\right)$ of cropland (Kassam et al. 2019 ) is primarily limited to large-scale commercial farms in North and South America, Australia, and New Zealand. Declining soil quality (physical, chemical, and biological) and incidence of weeds are addressed in large-scale farming by inputs of agrochemicals and use of other energy-based inputs. However, lack of appropriate seeding drills and competing uses of crop residues remain to be serious obstacles to adoption of CA by resourcepoor small landholders (Johansen et al. 2012). Capital and labor constraints also limit adoption of CA by small landholders (Grabowski 2011). Thus, there is a strong need to link researchers, farmers, and industry stakeholders to promote the adoption of CA (Naresh et al. 2014).

There are also concerns regarding a possibility of low crop yields and low or no accumulation of SOC by CA in degraded and depleted soils of both large and small landholder farmers. With the use of crop residue mulch and a systembased approach, however, adoption of CA by small landholders can enhance and sustain productivity under harsh conditions of rainfed farming (Rockström et al. 2009). A pertinent answer to the question of whether CA is a solution to dryland farming by small landholders is appropriately given by the positive results obtained from eastern and southern Africa (Kinyumu 2012; Araya et al. 2015; 2016) and elsewhere (Lal 2016b). Debate regarding the effects of CA on SOC sequestration and agronomic productivity (Govaerts et al. 2009; Powlson et al. 2011; Baker et al. 2007; Pittelkow et al. 2015), including the common observation that CA merely affects the distribution of SOC (stratification) in the surface layer rather than increasing its total amount (Piccoli et al. 2016), necessitates studies of a detailed soil/ecosystem $\mathrm{C}$ budget along with long-term measurements of SOC stocks to $\sim 1 \mathrm{~m}(3.28 \mathrm{ft})$ depth, and adopting site-specific management systems that create a positive soil C budget. Indeed, C-input differences is the main factor explaining the variability in SOC storage in NT compared to inversion tilled systems (Virto et al. 2012).

\section{CONSERVATION AGRICULTURE AND SOIL ORGANIC CARBON: SOME SUCCESS STORIES}

There are some examples of positive results of $\mathrm{CA}$ on agronomic yield and SOC sequestration. In the Loess Plateau of China, Lu et al. (2018) reported a positive net ecosystem $C$ value for a mulch-based CA system and a negative value with conventional moldboard plowing. Further, $\mathrm{Lu}$ and colleagues observed that conversion from plowing to CA caused SOC sequestration at the rate of 0.84 to $2.69 \mathrm{Mg} \mathrm{C}$ $\mathrm{ha}^{-1} \mathrm{y}^{-1}\left(0.37\right.$ to $\left.1.2 \mathrm{tn} \mathrm{ac}^{-1} \mathrm{yr}^{-1}\right)$. In the southeastern United States, Franzluebbers (2010) observed that the rate of SOC sequestration with adoption of CA was $0.45 \pm 0.04 \mathrm{Mg} \mathrm{C} \mathrm{ha}{ }^{-1} \mathrm{y}^{-1}(0.20 \pm 0.02$ tn $\left.\mathrm{C} \mathrm{ac}^{-1} \mathrm{yr}^{-1}\right)$. Analyzing data from longterm field experiments in the United States, Allmaras et al. (2000) reported the SOC storage in the order of NT > nonmoldboard tillage $>$ moldboard tillage system. Based on a 24-year study conducted in southern Illinois, United States, Olson et al. (2013) reported that NT plots retained $7.8 \mathrm{Mg} \mathrm{C} \mathrm{ha}^{-1}\left(3.48 \mathrm{tn} \mathrm{C} \mathrm{ac}^{-1}\right.$ ) more and chisel plow $-1.6 \mathrm{Mg} \mathrm{C} \mathrm{ha}{ }^{-1}$ $\left(-0.71 \mathrm{tn} \mathrm{C} \mathrm{ac}^{-1}\right)$ less SOC in the soil than moldboard plow. Further, the long-term productivity compared favorably with that of conventional tillage. Also, in southern Illinois, Walia et al. (2017) evaluated tillage and fertilizer management effects on SOC concentration to $1 \mathrm{~m}(3.28 \mathrm{ft})$ depth after 44 years of cultivation. Walia and colleagues observed that NT management increased SOC stocks and was even greater than that in the chisel tillage and forest soil to $1 \mathrm{~m}$ depth. The rate of SOC sequestration in NT for the top $15 \mathrm{~cm}(5.9$ in) depth over 44 years was $0.36 \mathrm{Mg} \mathrm{C}$ $\mathrm{ha}^{-1} \mathrm{y}^{-1}\left(0.16\right.$ tn $\left.\mathrm{C} \mathrm{ac}^{-1} \mathrm{yr}^{-1}\right)$. Based on a 13-year study in a semiarid Mediterranean agroecosystem of Lleida, Spain, Morell (2012) concluded that SOC stock under NT increased by 4.3 and $3.9 \mathrm{Mg} \mathrm{C} \mathrm{ha}{ }^{-1}$ (1.92 to 1.74 tn $\mathrm{C} \mathrm{ac}^{-1}$ ) in comparison to minimum tillage and conventional tillage. Further, input of medium and high $\mathrm{N}$ fertilization increased SOC stock by 3.4 and $4.5 \mathrm{Mg} \mathrm{C} \mathrm{ha}^{-1}$ (1.51 and 2.00 tn $\mathrm{C}$ $\left.\mathrm{ac}^{-1}\right)$. A 5-year study conducted in central Morocco on three soil types (Vertisol, Cambisol, and Luvisol) by Moussadek et al. (2014) indicated that SOC concentration in 0 to $30 \mathrm{~cm}$ (0 to 11.81 in) depth was significantly higher in NT than conventional tillage by $10 \%$ more in Vertisol and $8 \%$ more in Cambisol, but no difference in Luvisol. The average SOC stock in 0 to $30 \mathrm{~cm}$ depth was $29.4 \mathrm{Mg} \mathrm{C} \mathrm{ha}{ }^{-1}$ $\left(13.11\right.$ tn $\left.\mathrm{C} \mathrm{ac}^{-1}\right)$ under NT and $27.4 \mathrm{Mg}$ $\mathrm{C} \mathrm{ha}^{-1}$ (12.22 tn $\mathrm{C} \mathrm{ac}^{-1}$ ) under conventional tillage, an average increase of $0.4 \mathrm{Mg}$ $\mathrm{C} \mathrm{ha}^{-1} \mathrm{y}^{-1}\left(0.18\right.$ tn $\left.\mathrm{C} \mathrm{ac}^{-1} \mathrm{yr}^{-1}\right)$.

On a long-term basis, effectiveness of CA on SOC sequestration depends on a wide range of interacting factors including climate (especially the rainfall and its distribution) along with soil temperature regimes, soil properties, the amount and quality of the input of biomass, and the soil biodiversity. Virto et al. (2012) concluded that the $\mathrm{C}$ input differences may be the main factor explaining the variability in SOC storage in CA compared to inversion-tilled systems. Removal of stubble for grazing and other uses can reduce SOC stocks. Modeling studies in the state of Baden-Württemberg (southwestern Germany) by Gaiser et al. (2008) indicated the SOC sequestration rate of 0.08 to 1.82 $\mathrm{Mg} \mathrm{C} \mathrm{ha} \mathrm{y}^{-1} \mathrm{y}^{-1}$ (0.036 to 0.081 th $\mathrm{C} \mathrm{ac}^{-1}$ $\left.\mathrm{yr}^{-1}\right)$ in the state territory of $35,742 \mathrm{~km}^{2}$ $\left(13,800 \mathrm{mi}^{2}\right)$. Under conventional tillage, mean SOC losses through erosion were estimated at $0.45 \mathrm{Mg} \mathrm{C} \mathrm{ha-1} \mathrm{y}^{-1}(0.20 \mathrm{tn}$ $\left.\mathrm{C} \mathrm{ac}^{-1} \mathrm{yr}^{-1}\right)$. In the Colombian Andes, Quintero (2009) reported that SOC concentration in the whole profile was $29 \%$ higher under CA than that under conventional tillage, and that SOC sequestration especially occurred in the subsoil. Transfer of SOC in the subsoil is enhanced by the activity and species diversity of soil biota such as earthworms. Yet, there exists an urgent need to understand processes and identify appropriate management options that enhance activity and species diversity of soil biota, enhance soil health, and restore SOC stock. This is where systems of EI can play a pivotal role.

\section{TOWARD MAKING SOIL OF AGROECOSYSTEMS A CARBON SINK}

Soils of agroecosystems, croplands and pasturelands combined, cover about 5 Gha $\left(1.24 \times 10^{10} \mathrm{ac}\right)$ of manageable land area for soil $\mathrm{C}$ sequestration (table 


\section{Table 1}

Global land use (modified from Lal [2018] and FAO [2018] publications).

\begin{tabular}{lcc}
\hline Land use & Land area $\left(\mathbf{1 0}^{\mathbf{6}} \mathbf{h a}\right)$ & Percentage of the total ice-free land area $\mathbf{( \% )}$ \\
\hline Cropland & 1,590 & 12.0 \\
Pasture land & 3,270 & 25.0 \\
Forest land & 4,000 & 30.0 \\
(managed and natural) & & \\
Urban land & 730 & 0.6 \\
Other lands & 4,070 & 32.4 \\
\hline Total & 13,000 & 100.0
\end{tabular}

1). Site-specific adaptation of a systembased CA has a potential to make these soils a sink of atmospheric carbon dioxide $\left(\mathrm{CO}_{2}\right)$. Important determinants of SOC sink capacity of agroecosystems depend on numerous interacting factors (figure 1), including (1) pedo-climatic factors comprising of soil properties and climate parameters; (2) agroclimatic parameters comprising of judicious agronomic management especially that of nutrients, rotation, water, and integration with trees

\section{Figure 1}

Determinants of making soil under conservation agriculture (CA) a sink of atmospheric carbon dioxide. INM refers to integrated nutrient management based on judicious combination of organic and inorganic sources.

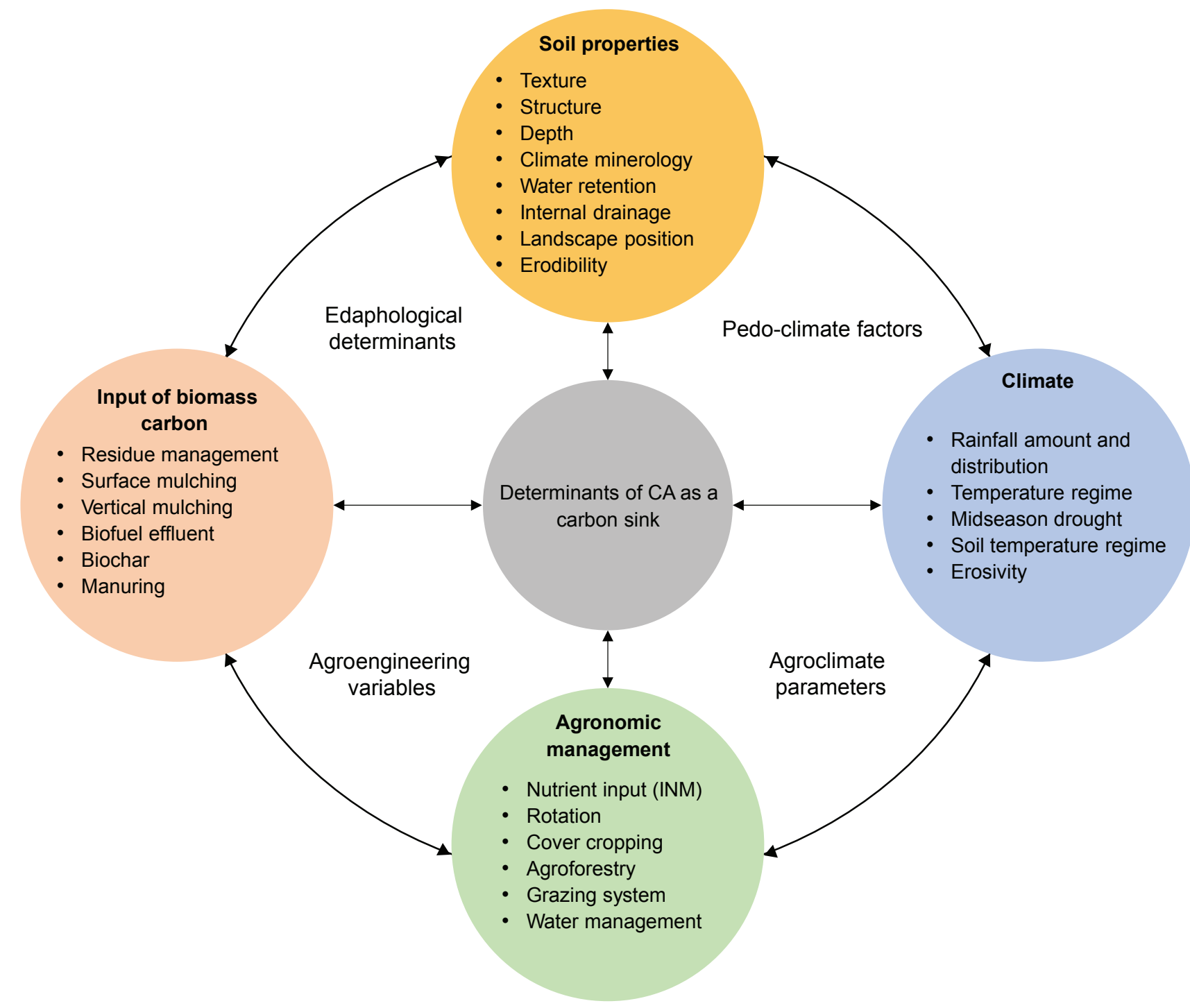


(agroforestry) and livestock (agropastoral); (3) agroengineering variables with regards to residues management, surface mulching, vertical mulching, application of effluent from biofuel feedstocks (i.e., Miscanthus [Miscanthus $\times$ giganteus $]$ ), and use of biochar; and (4) edaphological determinants of physical management of soil surface to reduce risks of crusting, compaction, poor aeration, and water imbalance (the drought-flood syndrome). Because there is no universal CA system, adaptation of CA to site-specific environments (biophysical and socioeconomic) is important to harness the potential SOC sink capacity.

\section{SUSTAINABLE SYSTEMS OF ECO-INTENSIFICATION}

There are notable differences in concepts, management, productivity, and environ- mental impact of organic farming (OF), sustainable intensification (SI), and EI (table 2). The principal strategy of SI is to increase production from existing farmland while restoring the environment (Garnett et al. 2013; Pretty 1997; Pretty et al. 2011; De Vivo et al. 2016; Tilman et al. 2011). However, innovative agroecosystems must also be pertinent to adapting and mitigating climate change, improving quality and renewability of water, enhancing biodiversity, and advancing Sustainable Development Goals (SDGs) of the United Nations. The needs for increasing food production and meeting other demands of growing and increasingly affluent world population must be met by adopting systems of land use and soil/crop/animal management that also restore quality of soil and other natural resources. Further, the meaning of the term SI is neither clear nor used in a standardized manner (Andres and Bhullar 2016; Petersen and Snapp 2016). There is also a lack of focus on improving soil health by restoring soil $\mathrm{C}$ (SOC and SIC) stocks through increasing inputs of biomass-C in soil. Thus, the term EI is more focused and specifically directed to improving soil health and the attendant processes (Peterson and Snapp 2016), and bringing about the much needed paradigm shift (Tchamitchian et al. 2011). Because of its relation to the environment on the one side and the human dimensions on the other (figure 2), EI is focused on restoring and sustaining soil health through improvement of soil $\mathrm{C}$ and strengthening its capacity for provisioning of ecosystem services.

\section{Table 2}

Comparative analysis between organic farming, sustainable intensification, and eco-intensification.

\begin{tabular}{|c|c|c|c|}
\hline Parameter & Organic farming & Sustainable intensification & Eco-intensification \\
\hline Fertility management & $\begin{array}{l}\text { Managing soil organic matter, } \\
\text { enhancing soil biological activity, } \\
\text { biological nitrogen fixation (BNF) }\end{array}$ & Using chemical fertilizers & $\begin{array}{l}\text { Integrated nutrient management } \\
\text { based on a judicious combination } \\
\text { of organic and inorganic sources, } \\
\text { biomass recycling, and BNF }\end{array}$ \\
\hline $\begin{array}{l}\text { Disease and pest } \\
\text { management }\end{array}$ & $\begin{array}{l}\text { Crop rotations, natural predators, } \\
\text { resistant varieties, diverse } \\
\text { cropping systems }\end{array}$ & $\begin{array}{l}\text { Chemical pest control: herbicides, } \\
\text { fungicides, insecticides }\end{array}$ & $\begin{array}{l}\text { Integrated pest management, creating } \\
\text { disease suppressive soils, judicious } \\
\text { chemical intervention, and enhancing } \\
\text { biodiversity }\end{array}$ \\
\hline Seedbed preparation & $\begin{array}{l}\text { Mechanical tillage for weed control, } \\
\text { residues incorporation, and manure } \\
\text { management }\end{array}$ & No-till based on chemical weed control & $\begin{array}{l}\text { Conservation agriculture based on a } \\
\text { system approach: (1) residue mulch, } \\
\text { (2) no-till, (3) complex rotations, } \\
\text { (4) cover cropping, (5) integrated } \\
\text { nutrient management }\end{array}$ \\
\hline $\begin{array}{l}\text { Risks of soil degradation } \\
\text { and pollution }\end{array}$ & $\begin{array}{l}\text { No soil pollution but high risks of soil } \\
\text { erosion because of mechanical tillage }\end{array}$ & High risks of soil pollution by chemicals & $\begin{array}{l}\text { Conservation-effective with minimal } \\
\text { risks of soil degradation and } \\
\text { environmental pollution }\end{array}$ \\
\hline Agronomic yield & Low & High but not sustained & $\begin{array}{l}\text { Optimal but sustained with creation of } \\
\text { better environment and regreening } \\
\text { of landscape }\end{array}$ \\
\hline Gaseous emission & Low & Very high & Moderate and often emission-negative \\
\hline System approach & $\begin{array}{l}\text { High diversity of crops, integrated } \\
\text { with trees and livestock }\end{array}$ & $\begin{array}{l}\text { Improved varieties grown with high input } \\
\text { of fertilizers and supplemental irrigation }\end{array}$ & $\begin{array}{l}\text { Integrated soil-crop-livestock-tree } \\
\text { systems to enhance soil and } \\
\text { environmental health by using } \\
\text { conservation agriculture and } \\
\text { sequestering carbon }\end{array}$ \\
\hline
\end{tabular}




\section{Figure 2}

Eco-intensification of agroecosystems for harnessing ecosystem services and advancing Sustainable Development Goals of the United Nations: \#1 no poverty; \#2 zero hunger; \#3 good health and wellbeing; \#6 clean water and sanitation; \#11 sustainable cities; \#13 climate action; \#15 life on land; and \#16 peace, justice, and strong institution.
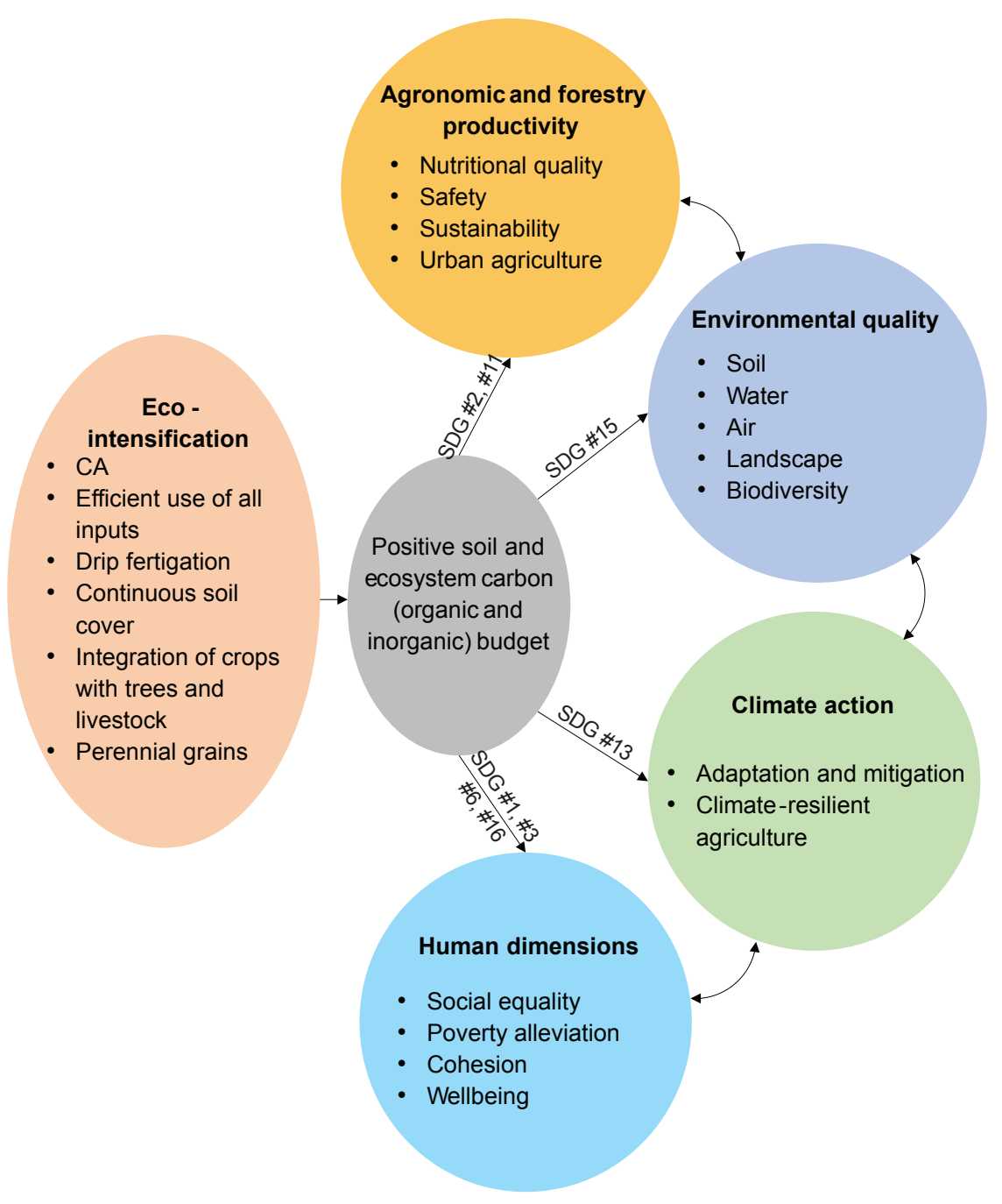

The goal of $\mathrm{OF}$ is to eliminate the use of chemicals; it has its niches, but also limitations (table 2). However, EI is not limited to OF per se. The strategy of EI involves judicious use of inputs (both organic and inorganic) to meet the soil/ farming system demands for nutrients, water, and pest control. The impact of EI goes beyond increase in agronomic productivity. The latter can be achieved by genetic engineering and biotechnology on a short-term basis (South et al. 2019), but it cannot be sustained unless soil health and water quality are also enhanced.
Neglecting soil and water resources and increasing productivity through plant improvement alone has and can create serious environmental hazards. In contrast, EI in conjunction with improved germplasm is a real paradigm shift because it also minimizes the risks of environmental degradation. Adoption of EI is critical to enhancing soil quality/health (Bünemann et al. 2018) and to developing climateresilient systems against the drought-flood syndrome. Excessive and indiscriminate use of chemicals, leading to pollution, contamination, and eutrophication, must be avoided. Thus, EI implies harnessing of ecosystem services (Bommarco et al. 2013) while restoring soil resources, mitigating gaseous emissions from agroecosystems (Burney et al. 2010), and sustaining productivity. The need for a paradigm shift in agroecosystems (Fedoroff et al. 2010) can be met through EI (Hochman et al. 2013) by farming for ecosystem services (Robertson et al. 2014) while advancing the SDGs (figure 2).

\section{CONCLUSION}

Soils of agroecosystems are an important sink of atmospheric $\mathrm{CO}_{2}$. With the necessity of limiting the global warming to $1.5^{\circ} \mathrm{C}\left(2.7^{\circ} \mathrm{F}\right)$ and restoring the environment, the strategy is to manage soils of agroecosystems to harness ecosystem services while restoring the environment and advancing SDGs of the United Nations. The needed paradigm shift in agriculture can be met through adoption of the strategy of EI, which implies managing soils of agroecosystems to be climate-resilient by adapting and mitigating anthropogenic climate change, improving quality and renewability of water, enhancing biodiversity, improving human wellbeing, and conserving nature. There are notable differences in concepts, practices, and soil/ environmental impacts among OF, SI, and EI. The latter involves the concept of producing more from less while restoring soil health and improving the environment. Examples of farming practices for adopting EI include CA, perennial culture, and integration of crops with livestock. Because CA may neither always produce the desired yield nor sequester soil $\mathrm{C}$, fine-tuning based on a soil-guide and techniques that create a positive soil/ecosystem C budget (e.g., cover cropping and earthworm activity) must be identified. The goal is to adapt the CA system and make it work because of its numerous cobenefits. While OF has its niches, EI implies a judicious/prudent use of all inputs (organic and inorganic), improving use efficiency and reducing their leakage into the environment.

\section{REFERENCES}

Alexandratos, N., and J. Bruinsma. 2012. World agriculture towards 2030/2050. ESA Working 
paper No. 12-03. Rome: Food and Agriculture Organization of the United Nations, Agriculture Development Economics Division.

Allmaras, R.R., H.H. Schomberg, C.L. Douglas, and T.H.Dao. 2000. Soil organic carbon sequestration potential of adopting conservation tillage in US croplands. Journal of Soil and Water Conservation 55(3):365-373.

Andres, C., and G.S. Bhullar. 2016. Sustainable intensification of tropical agro-ecosystems: Need and potentials. Frontiers in Environmental Science 4 (February 2, 2016).

Araya, T., J. Nyssen, B. Govaerts, F. Baudron, L. Carpentier, H. Bauer, S. Lanckriet, J. Deckers, and W.M. Cornelis. 2016. Restoring cropland productivity and profitability in northern Ethiopian drylands after nine years of resourceconserving agriculture. Experimental Agriculture 52(2):165-187.

Araya, T., J. Nyssen, B. Govaerts, J. Deckers, and W.M. Cornelis. 2015. Impacts of conservation agriculture-based farming systems on optimizing seasonal rainfall partitioning and productivity on vertisols in the Ethiopian drylands. Soil and Tillage Research 148(2015):1-13.

Arizpe, N., M. Giampietro, and J. Ramos-Martin. 2011. Food security and fossil energy dependence: An international comparison of the use of fossil energy in agriculture (1991-2003). Critical Reviews in Plant Sciences 30(1-2):45-63.

Bai, Z.G., D.L. Dent, L. Olsson, and M.E. Schaepman. 2008. Proxy global assessment of land degradation. Soil Use and Management 24(3):223-234.

Baker, J.M., T.E. Ochsner, R.T. Venterea, and T.J. Griffis. 2007. Tillage and soil carbon sequestration-What do we really know? Agriculture, Ecosystems and Environment 118(1-4):1-5.

Beddington, J., M. Asaduzzaman, M. Clark, A. Fernández, M. Guillou, M.Jahn, L. Erda,T. Mamo, N. Van Bo, C.A. Nobre, R. Scholes, R. Sharma, and J. Wakhungu. 2012. Achieving food security in the face of climate change: Summary for policy makers from the Commission on Sustainable Agriculture and Climate Change. Wageningen, Netherlands: CGIAR Research Program on Climate Change, Agriculture and Food Security.

Benson, M. 2014. The end of sustainability. Society and Natural Resources 27(7):777-782.

Bindraban, P.S., M. van der Velde, L. Ye, M. van den Berg, S. Materechera, D.I. Kiba, L. Tamene, K.V. Ragnarsdóttir, R. Jongschaap, M. Hoogmoed, W. Hoogmoed, C. van Beek, and G. van Lynden. 2012. Assessing the impact of soil degradation on food production. Current Opinion in Environmental Sustainability 4(5):478-488.
Bommarco, R., D. Kleijn, and S.G. Potts. 2013. Ecological intensification: Harnessing ecosystem services for food security. Trends in Ecology and Evolution 28(4):230-238.

Brandt, C., G. Dercon, G. Cadisch, L.T. Nguyen, P. Schuller, C.B. Linares, A.C. Santana, V. Golosov, M. Benmansour, N. Amenzou, Z. Xinbao, and F. Rasche. 2018. Towards global applicability? Erosion source discrimination across catchments using compound-specific $\delta 13 \mathrm{C}$ isotopes. Agriculture, Ecosystems and Environment 256(2018):114-122.

Bruinsma, J. 2009. The resource outlook to 2050: By how much do land, water, and crop yields need to increase by 2050? In Expert Meeting on How to Feed the World in 2050, 24-26. Rome: Food and Agriculture Organization of the United Nations Economic and Social Development Department. Buck, P. 2012. The Good Earth. New York, NY: Open Road Media.

Bünemann, E., G. Bongiorno, Z. Bai, R. Creamer, G. De Deyn, R. de Goede, L. Flesken, V. Geissen, T. Kuyper, P. Mader, M. Pulleman, W. Sukkel, J. van Groenigen, and L. Brussaard. 2018. Soil qualityA critical review. Soil Biology and Biochemistry 120 (2018):105-125.

Burney, J.A., S.J. Davis, and D.B. Lobell. 2010. Greenhouse gas mitigation by agricultural intensification. Proceedings of the National Academy of Sciences 107(26):12052-12057.

De Vivo, R., A. Marchis, E. Gonzalez-Sanches, and E. Capri. 2016. The sustainable intensification of agriculture. Solutions 7(5):24-31.

Drinkwater, L., and S. Snapp. 2007. Nutrients in agroecosystems: Rethinking the management paradigm. Advances in Agronomy 92(2007):163-186.

FAO (Food and Agriculture Organization of the United Nations). 2002. Towards 2015/2030 World Agriculture; Summary Report. Rome: Food and Agriculture Organization of the United Nations.

FAO. 2018. FAOSTATS. Rome: Food and Agriculture Organization of the United Nations. http://www.fao.org/faostat/en/.

FAO and ITPS (Intergovernmental Technical Panel on Soils). 2015. The World's Soil Resources: Main Report. Rome: Food and Agriculture Organization of the United Nations.

Faulkner, E. 1943. Plowman's Folly. Norman, OK: University of Oaklahoma Press.

Fedoroff, N.V., D.S. Battisti, R.N. Beachy, P.J.M. Cooper, D.A. Fischhoff, C.N. Hodges, V.C. Knauf, D. Lobell, B.J. Mazur, D. Molden, M.P. Reynolds, P.C. Ronald, M.W. Rosegrant, P.A. Sanchez, A.Vonshak, and J.K. Zhu. 2010. Radically rethinking agriculture for the 21st century. Science 327(5967):337.
Foley, J.A., N. Ramankutty, K.A. Brauman, E.S. Cassidy, J.S. Gerber, M. Johnston, N.D. Mueller, C. O’Connell, D.K. Ray, P.C. West, C. Balzer, E.M. Bennett, S.R. Carpenter, J. Hill, C. Monfreda, S. Polasky, J. Rockström, J. Sheehan, S. Siebert, D. Tilman, and D.P.M. Zaks. 2011. Solutions for a cultivated planet. Nature 478(7369):337.

Franzluebbers, A.J. 2010. Achieving soil organic carbon sequestration with conservation agricultural systems in the southeastern United States. Soil Science Society of America Journal 74(2):347-357.

Gaba, S., F. Bretagnolle, T. Rigaud, and L. Philippot. 2014. Managing biotic interactions for ecological intensification of agroecosystems. Frontiers in Ecology and Evolution 2 (June 30, 2014).

Gaiser, T., K. Stahr, N. Billen, and M.A.R. Mohammad. 2008. Modeling carbon sequestration under zero tillage at the regional scale. I. The effect of soil erosion. Ecological Modelling 218(1-2):110-120.

Garnett, T., M. Appleby, A. Balmford, I. Bateman, T. Benton, P. Bloomer, B. Burlingame, M. Dawkins, L. Dolan, D. Fraser, M. Herrero, I. Hoffmann, P. Smith, P. Thronton, C. Toulmin, S. Vermeulen, and H. Godfray. 2013. Sustainable intensification in agriculture: Premises and policies. Science 341(2013):33-34.

Gomiero, T. 2016. Soil degradation, land scarcity and food security: Reviewing a complex challenge. Sustainability (Switzerland) 8(3):281.

Govaerts, B., N. Verhulst, A. Castellanos-Navarrete, K.D. Sayre, J. Dixon, and L. Dendooven. 2009. Conservation agriculture and soil carbon sequestration: Between myth and farmer reality. Critical Reviews in Plant Sciences 28(3):97-122.

Grabowski, P. 2011. Constraints to adoption of conservation agriculture in the Angonia highlands of Mozambique: Perspectives from smallholder hand-hoe farmers. Master's thesis, Michigan State University.

Grandy, A.S., G.A. Porter, and M.S. Erich. 2002. Organic amendment and rotation crop effects on the recovery of soil organic matter and aggregation in potato cropping systems. Soil Science Society of America Journal 66(4):1311-1319.

Grassini, P., K.M. Eskridge, and K.G. Cassman. 2013. Distinguishing between yield advances and yield plateaus in historical crop production trends. Nature Communications 4(2013):2918.

Hochman, Z., P.S. Carberry, M.J. Robertson, D.S. Gaydon, L.W. Bell, and P.C. McIntosh. 2013. Prospects for ecological intensification of Australian agriculture. European Journal of Agronomy 44 (2013):109-123. 
Jacks, G.V., and R.O. Whyte. 1939. The Rape of the Earth: A World Survey of Soil Erosion. London: Faber and Faber.

Johansen, C., M. Haque, R. Bell, C. Thierfelder, and R. Esdaile. 2012. Conservation agriculture for small holder rainfed farming: Opportunities and constraints of new mechanized seeding systems. Field Crops Research 132(2012):18-32.

Kassam,A.,T. Friedrich, and R.Derpsch. 2019. Global spread of Conservation Agriculture. International Journal of Environmental Studies 76(1):29-51.

Kinyumu, D.M. 2012. Is conservation agriculture a solution to dry land rain-fed farming? Experiences and perceptions of smallholder farmers in Laikipia District, Kenya. Journal of Developments in Sustainable Agriculture 7(2):134-147.

Lal, R. 2010. Enhancing eco-efficiency in agroecosystems through soil C sequestration. Crop Sci. 50:S120-S131.

Lal, R. 2015. A system approach to conservation agriculture. Journal of Soil and Water Conservation 70(4):82A-88A, doi:10.2489/jswc.70.4.82A.

Lal, R. 2016a. Feeding 11 billion on 0.5 billion hectare of area under cereal crops. Food and Energy Security 5(4):239-251.

Lal, R. 2016b. Potential and challenges of conservation agriculture in sequestration of atmospheric $\mathrm{CO}_{2}$ for enhancing climate-resilience and improving productivity of soil of small landholder farms. CAB Reviews 11:009; doi:10.1079/ PAVSNR201611009.

Lal, R. 2017. Feeding megacities by urban agriculture. In Urban Soils, Advances in Soil Science, ed. R. Lal and B. Stewart, 375-390. Boca Raton: CRC Press.

Lal, R. 2018. Saving global land resources by enhancing eco-efficiency of agroecosystems. Journal of Soil and Water Conservation 73(4):100A-106A, doi:10.2489/jswc.73.4.100A.

Lambin, E.F., H.K. Gibbs, L. Ferreira, R. Grau, P. Mayaux, P. Meyfroidt, D.C. Morton, T.K. Rudel, I. Gasparri, and J. Munger. 2013. Estimating the world's potentially available cropland using a bottom-up approach. Global Environmental Change 23(5):892-901.

Lu, X., X. Lu, and Y. Liao. 2018. Conservation tillage increases carbon sequestration of winter wheatsummer maize farmland on Loess Plateau in China. PLoS ONE 13(9):e0199846.

Michael,A., J. Schmidt, W. Enke, T. Deutschländer, and G. Malitz. 2005. Impact of expected increase in precipitation intensities on soil loss - Results of comparative model simulations. Catena 61(2-3):155-164.

Morell, J.S. 2012. Soil organic carbon dynamics and carbon sequestration in a semiarid Mediterranean agroecosystem: Effects of conservation tillage and nitrogen fertilization. Spain: Universitat de Lleida.

Moussadek, R., R. Mrabet, R. Dahan, A. Zouahri, M. El Mourid, and E.Van Ranst. 2014.Tillage system affects soil organic carbon storage and quality in central Morocco. Applied and Environmental Soil Science (2014):1-8.

Naresh, R.K., R.K. Gupta, A.K. Misra, K. Dipender, K. Vineet, and K. Vikas. 2014. Conservation agriculture for small holder irrigated farming: Opportunities and constraints of new mechanized seeding systems: A review. International Journal of Life Sciences Biotechnology and Pharma Research 3(1):1-41.

Oldeman, L. 1994. The global extent of soil degradation. In Soil Resilience and Sustainable Land Use, eds. D. Greenland and I. Szabols, 99-118. Wallingford, UK: CAB International.

Olson, K.R., S.A.Ebelhar, and J.M.Lang. 2013. Effects of 24 years of conservation tillage systems on soil organic carbon and soil productivity. Applied and Environmental Soil Science (2013):1-10.

Petersen, B., and S. Snapp. 2016. Corrigendum to "What is sustainable intensification: Views from experts." Land Use Policy: The International Journal Covering All Aspects of Land Use 58 (2016):558-559.

Piccoli, I., F. Chiarini, P. Carletti, L. Furlan, B. Lazzaro, S. Nardi, A. Berti, L. Sartori, M.C. Dalconi, and F. Morari. 2016. Disentangling the effects of conservation agriculture practices on the vertical distribution of soil organic carbon. Evidence of poor carbon sequestration in North- Eastern Italy. Agriculture, Ecosystems and Environment 230(2016):68-78.

Pittelkow, C.M., X. Liang, B.A. Linquist, L.J. Van Groenigen, J. Lee, M.E. Lundy, N. Van Gestel, J. Six, R.T. Venterea, and C. Van Kessel. 2015. Productivity limits and potentials of the principles of conservation agriculture. Nature 517(2015):365-368.

Powlson, D.S., A.P. Whitmore, and K.W.T. Goulding. 2011. Soil carbon sequestration to mitigate climate change: A critical re-examination to identify the true and the false. European Journal of Soil Science January 17, 2011. https://doi. org/10.1111/j.1365-2389.2010.01342.x.

Pretty,J.N. 1997.The sustainable intensification of agriculture. Natural Resources Forum 21(4):247-256.

Pretty, J., C. Toulmin, and S. Williams. 2011. Sustainable intensification in African agriculture. International Journal of Agricultural Sustainability 9(1):5-24.

Quintero, M. 2009. Effects of conservation tillage in soil carbon sequestration and net revenues of potato-based rotations in the Colombian Andes. Master's thesis, University of Florida.

Rekacewicz,P.2008.Global SoilDegradation.UNEP/ GRID-Arendal-From Collection: IAASTDInternational Assessment of Agricultural Science and Technology for Development. http://www. grida.no/resources/6338.

Robertson, G.P., K.L. Gross, S.K. Hamilton, D.A. Landis, T.M. Schmidt, S.S. Snapp, and S.M. Swinton. 2014. Farming for ecosystem services: An ecological approach to production agriculture. BioScience 64(5):404-415.

Rockström, J., P. Kaumbutho, J. Mwalley, A.W.W. Nzabi, M. Temesgen, L. Mawenya, J. Barron, J. Mutua, and S. Damgaard-Larsen. 2009. Conservation farming strategies in East and Southern Africa:Yields and rain water productivity from on-farm action research. Soil and Tillage Research 103(1):23-32.

Smil, V. 2003. Energy at the Crossroads. Cambridge, MA:The MIT Press.

South, P.F., A.P. Cavanagh, H.W. Liu, and D.R. Ort. 2019. Synthetic glycolate metabolism pathways stimulate crop growth and productivity in the field. Science 363(6422):eaat9077.

Steinbeck, J. 1939. The Grapes of Wrath. New York: Penguin Classics.

Tchamitchian, M., N. Munier-Jolain, T. Doré, P. Tittonell, D. Makowski, and E. Malézieux. 2011. Facing up to the paradigm of ecological intensification in agronomy: Revisiting methods, concepts and knowledge. European Journal of Agronomy 34(4):197-210.

Tilman, D., C. Balzer, J. Hill, and B.L. Befort. 2011. Global food demand and the sustainable intensification of agriculture. Proceedings of the National Academy of Sciences 108(50):20260-20264.

Tilman, D., J. Fargione, B. Wolff, C. D’Antonio, A. Dobson, R. Howarth, D. Schindler, W.H. Schlesinger, D. Simberloff, and D. Swackhamer. 2001. Forecasting agriculturally driven global environmental change. Science 292(2001):281-284.

Virto, I., P. Barré, A. Burlot, and C. Chenu. 2012. Carbon input differences as the main factor explaining the variability in soil organic C storage in no-tilled compared to inversion tilled agrosystems. Biogeochemistry 108(1-3):17-26.

Walia, M., S. Baer, R. Krausz, and R.L. Cook. 2017. Deep soil carbon after 44 years of tillage and fertilizer management in southern Illinois compared to forest and restored prairie soils. Journal of Soil and Water Conservation 72(4):405-415, doi:10.2489/jswc.72.4.405.

Wood, A. 1951. The Groundnut Affair. London, England:The Bodley Head. 